\title{
OBESITY: GENOME AND ENVIRONMENT INTERACTIONS
}

\author{
Martina BAŠIĆ, Ana BUTORAC, Irena LANDEKA JURČEVIĆ, and Višnja BAČUN-DRUŽINA \\ Faculty of Food Technology and Biotechnology, University of Zagreb, Zagreb, Croatia
}

Received in March 2012

CrossChecked in July 2012

Accepted in July 2012

\begin{abstract}
Obesity has become one of the major threats for public health in industrialised world among adults, but also among adolescents and children. It is influenced by the interaction of genes, nutrition, environment, and lifestyle. Environmental and lifestyle risk factors include foetal and lifelong environment, nutrient quality, chemical and microbial exposure, and psychical stress, all of which are important contributing influences. Removing or limiting chemical and pharmaceutical obesogens from human environment could make a difference in the growing epidemic of obesity.

Additionally, nutrigenomics describes how modifications in individual diets can improve health and prevent chronic diseases, as well as obesity, by understanding the effects of a genetic profile in the interaction between food and increase in body weight. Furthermore, individual genetic variations in genome represent an individual's predisposition for obesity. Therefore, the use of individual genetic information, avoiding obesogens, and a healthy lifestyle could help to improve the management of obesity and maintain a healthy weight.
\end{abstract}

KEY WORDS: genes, nutrigenomics, nutrition, obesogens

The growing prevalence of obesity and the fact that its management is mostly ineffective are opening novel fields of research - investigation of genes, environment, and their interactions with the intention to create a concept of personalised medicine and nutrition (1).

Obesity and its implications for human health decrease the quality of life and life expectancy considerably, as they increase the risk of a great number of chronic diseases (2-10; table 1). Excess weight and obesity are the consequences of a higher energy intake and lower energy expenditure, which results in a positive energy balance (11). Several biological changes in our body are related with the state of overweight and obesity (Figure 1).

Obesity is a disease which affects not only the individual, but also the public health. It is influenced by many factors such as genetic and epigenetic predisposition, metabolic, hormonal, environmental, behavioural, social, and cultural aspects (12). This is why it is important to better understand obesity and its aetiology and find more effective prevention and treatment tools.

\section{Genetic aspect of obesity}

Individual human differences and genetic variations influence the risk of becoming obese (11). At present, over 100 genes are under discussion for their effect on obese phenotypes. The latest update of the Human Obesity Gene Map, which was created in 2005, focuses on 253 groups of genes related to obesity (13). This catalogue of obesity genes shows that putative loci affecting obesity-related phenotypes are situated on all chromosomes except Y. Table 2 displays five categories of the most investigated obesity-related genes in recent years (13-16, Figure 1). 


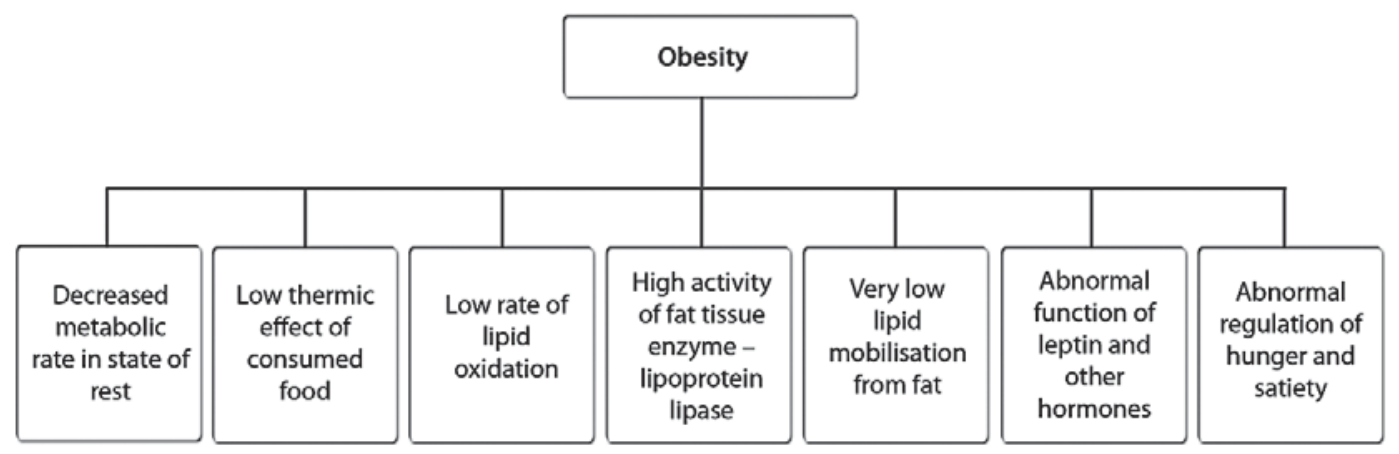

Figure 1 The physiological changes associated with obesity

The studies on both humans and animals showed that different genes play roles in different responses to weight gain or weight loss, and that body defence against losing fat/weight is greater than that against gaining fat/weight (17). Also, the weight loss response to (dietary) interventions varies. Many genes involved in the regulation of energy balance, appetite, lipid metabolism, and adipogenesis have been reported to affect the risk of dietary intervention failure in some individuals. Some of these genes have already been mentioned: $\beta$-adrenergic receptor (ADBR), uncoupling proteins (UCPs), leptin (LEP), leptin receptor (LEPR), melanocortin receptor 3 (MC3R), pro-opiomelanocortin (POMC), and interleukin 6 (IL-6) (18, Table 2).

In studies involving adult monozygotic twins (19, 20) who were overfed and whose energy intake or exercise were restricted (21-23), it was shown that the predisposition to increase or decrease body fat was genetically based (1).

Mammes et al. (2001) reported that a $\mathrm{G}>\mathrm{A}$ transition at position -2549 in the promoter region of the LEP gene is associated with obesity and that carriers of the -2549A allele have higher leptin levels and lower weight loss as a response to low calorie intake $(24,25)$. Furthermore, carriers of a variant $C$ allele in the LEPR gene [Ser (T) 343Ser (C)] have lost more weight in response to a low calorie intake than the noncarriers (26).

In a study of the Lys656Asn variant within LEPR, homozygotes for the Lys656 allele had a considerable loss of body weight, fat mass, waist circumference, and a decrease in body mass index (BMI), systolic blood pressure, and leptin levels, compared to the carriers of the Asn656 allele (27). Some studies have investigated the effect of a polymorphism in the peroxisome proliferator-activated receptor $\gamma(\operatorname{PPAR} \gamma)$ gene, Pro12Ala. Lindi et al. (28) showed that Ala12 carriers increased body weight considerably in a period of 10 years. However, Ala12Ala homozygotes had, in the same period of time, lower levels of fasting plasma insulin, regardless of the increased body weight. In another study, Ala12 carriers on a hypocaloric diet lost almost the same body weight as Pro12 homozygotes during a period of six months, but unlike Pro12 homozygotes, they gained more weight after the hypocaloric treatment was completed (29).

Candidate gene variants for polygenic obesity appear to disrupt pathways involved in the regulation of energy intake and expenditure and include adrenergic receptors, uncoupling proteins, PPAR $\gamma$, POMC, melanocortin receptor 4 (MC4R), and a set of single nucleotide polymorphisms in the fat mass and obesity (FTO) locus. Obviously, obesity polygenic character involves complex gene-gene and geneenvironment interactions and their mutual interactions that result in multi-factorial obese phenotypes (for reviews see 30-32).

\section{Environmental obesogens}

Human diseases are entirely or partially caused by environmental chemicals, which introduce genetic and/or epigenetic changes in the genome. Heritable changes in gene expression exclude any modification of the primary DNA sequence. However, they lead to chromatin remodelling through DNA methylation, a complex set of histone modifications, and the influence of non-coding RNAs. Besides the changes in the epigenetic status (33), lifestyle, dietary intakes, and environmental chemicals affect cell transcriptional factors $(34)$, hormones $(35,36)$, inflammatory mechanisms (37), and gut microbiome in certain organisms (38-41), all of which are contributing factors for obesity epidemic (42-44, Figure 1). The 
most important molecular and/or cellular changes that are reflected on obesity phenotypes appearance are further described.

Obesogens (Figure 1) are foreign endocrine disrupting chemicals (EDCs) that inappropriately alter normal development and/or homeostasis of lipid metabolism, adipogenesis, fat storage, obesity, and type 2 diabetes $(4,45-48)$. EDCs can interfere with normal functions of the endocrine system by disrupting the balanced system of hormones that regulate vital body functions such as growth, stress response, sex development, behaviour, ability to reproduce, production and utilisation of insulin, and metabolic rate. Recent experiments on animals confirmed that EDCs can disrupt the gene-controlled, normal signalling systems that determine every aspect of foetal development. Furthermore, epidemiology studies indicate that exposure to EDCs during the development of a foetus is associated with excess weight and obesity later in life (49).

It has been proposed that dangerous environmental obesogens can be categorised into the following groups of compounds: endocrine disrupting chemicals organotins and bisphenol A (BPA), perfluorooctanoic acid, diisobutyl phthalate, and pharmaceutical obesogens such as thiazolidinediones: rosiglitazone and pioglitazone $(45,47,48)$.

Organotins are widespread persistent environmental organic pollutants with potent endocrine-disrupting properties in both vertebrates and invertebrates. They are used as fungicides and pesticides in crops, antifungal agents in wood treatments, slimicides in

Table 1 Obesity related diseases or disorders

\begin{tabular}{|c|c|c|}
\hline Disease / disorder & Relation with obesity & Source/publication \\
\hline Type II diabetes & $\begin{array}{l}80 \% \text { correlation of type II diabetes and obesity } \\
85 \% \text { of children with type II diabetes are obese } \\
\text { Term "diabesity" underscores the strong } \\
\text { connection }\end{array}$ & Lau, $2008(2)$ \\
\hline Cardiovascular diseases & Correlation with obesity in $70 \%$ of cases & Lau, $2008(2)$ \\
\hline $\begin{array}{l}\text { Metabolic syndrome } \\
\text { Hypertension } \\
\text { Elevated plasma insulin } \\
\text { concentrations } \\
\text { Insulin resistance } \\
\text { Hyperglycaemia } \\
\text { Hyperlipidaemia }\end{array}$ & $\begin{array}{l}\text { Higher risk associated with intraabdominal } \\
\text { visceral fat } \\
\text { tissue }\end{array}$ & Kopelman, 2007 (3) \\
\hline $\begin{array}{l}\text { Gout, liver disease, asthma and } \\
\text { pulmonary problems, gall bladder } \\
\text { disease, kidney disease, osteoarthritis }\end{array}$ & Strong connection with obesity and excess weight & $\begin{array}{l}\text { Newbold, } 2010 \text { (4) } \\
\text { Chlebowski, } 2005 \text { (5) }\end{array}$ \\
\hline Cancer & Connection with colon and breast cancer $42 \%$ & Lau, $2008(2)$ \\
\hline Breast cancer & $\begin{array}{l}\text { Obesity associated with breast cancer recurrence } \\
\text { and mortality through low physical activities, high } \\
\text { calorie and fat intake, and changes in hormones } \\
\text { (high oestrogen production in adipose tissue) }\end{array}$ & $\begin{array}{l}\text { Chlebowski, } 2005 \text { (5), } \\
\text { Sauter et al., } 2008 \text { (6), } \\
\text { Rose and Vona-Davis, } \\
2010(7)\end{array}$ \\
\hline Prostate cancer & $\begin{array}{l}\text { More aggressive forms are diagnosed in men with } \\
\text { higher BMI (by } 15 \% \text { to } 21 \% \text { higher risk of fatal } \\
\text { prostate cancer or biochemical recurrence) } \\
12 \% \text { to } 20 \% \text { of prostate cancer deaths connected } \\
\text { with obesity }\end{array}$ & $\begin{array}{l}\text { Strom et al.,2005 (8), } \\
\text { Cao and Ma, } 2011 \text { (9) }\end{array}$ \\
\hline $\begin{array}{l}\text { Chronic musculoskeletal problems, } \\
\text { lumbago, skin problems, obstructive } \\
\text { sleep apnoea }\end{array}$ & Decreased physical activity, BMI $>30$ & $\begin{array}{l}\text { Kanasaki and Koya, } \\
2011 \text { (10) }\end{array}$ \\
\hline
\end{tabular}




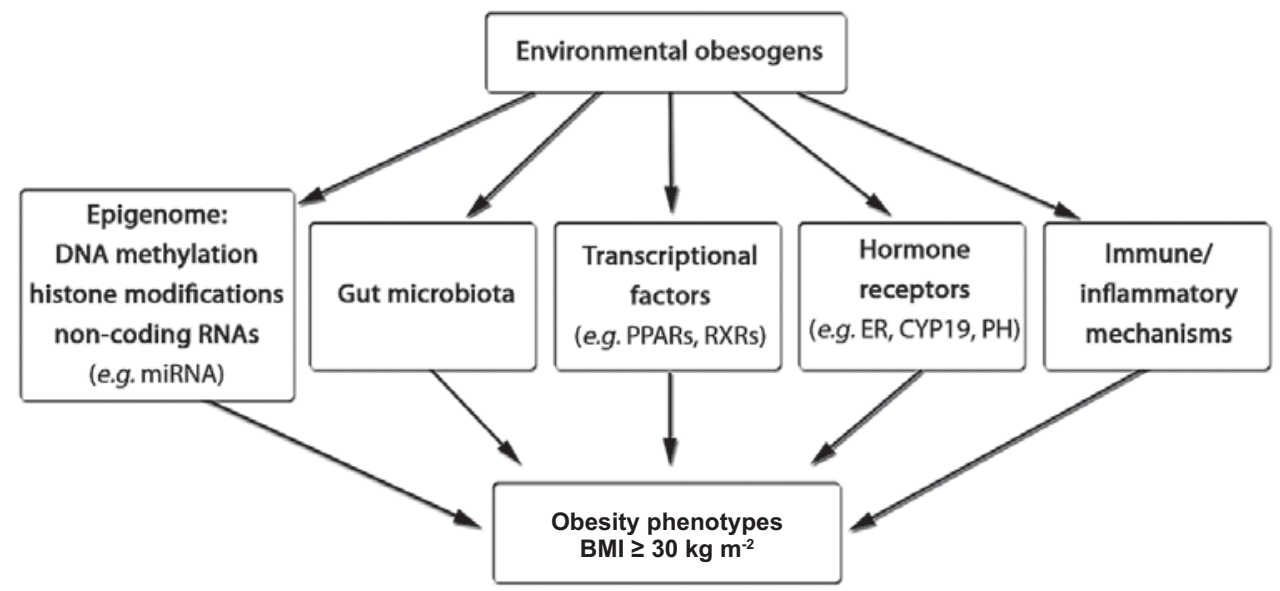

Figure 2 Possible targets of obesogens. Environmental obesogens influence a variety of molecular and/or cellular targets that may act either alone or with each other creating a complex network that affects gene expression and results in obesity phenotypes (abbreviations: miRNA - microRNA, PPARs - peroxisome proliferator-activated receptors, RXRs-retinoid $X$ receptors, ER - oestrogen receptor, CYP19 - Cytochrome aromatase p450, PH-peptidergic hormones, BMI - body mass index).

industrial water systems, marine antifouling agents, in polyvinylchloride plastics, and in the textile industry $(45,47,48)$. Contaminated drinking water, agricultural products, seafood, and leaching from plastics are the most frequent sources of organotins (50-52). Organotins such as tributyltin (TBT) and triphenyltin are potent activators of nuclear hormone receptors retinoid $X$ receptor ( $\mathrm{RXR} \alpha,-\beta$, and $-\gamma$ ) and peroxisome proliferator-activated receptor $\gamma$ which regulate adipocyte number, size, and function (53). Moreover, the organotin compound tributyltin, an agonist of both retinoid X receptor and peroxisome proliferatoractivated receptor $\gamma$, alters the fate of stem cell compartment by sensitising multipotent stromal stem cells to differentiate into adipocytes (49). More recently, studies have confirmed that TBT and tetrabromobisphenol A modify hypothalamic gene regulations resulting in hypothalamic dysregulations (54).

Bisphenol A as a component of polycarbonate plastics is widely used in numerous products such as polycarbonate baby bottles, beverage containers, the linings of food cans, dental composites, and sealants (4). BPA has a potential to bind to the nuclear oestrogen receptor and interact with a variety of other targets in mammalian cells. In addition to acting as an androgen receptor antagonist, BPA interacts with thyroid hormone receptors (55). A variety of abnormalities in the female and male reproductive and mammary gland tissues were found after perinatal exposure to low doses of BPA (55). Exposure to low doses of BPA during prenatal and neonatal periods affected both mice and rats insomuch as their body weight increased (57-60).

Perfluorooctanoic acid and phthalates can negatively affect the adipose homeostasis and lipids. These classes of chemicals include various perfluoroalkyl compounds and phthalate plasticisers that are widely used as surface repellents and surfactants.

Pharmaceutical obesogens, rosiglitazone and pioglitazone (thiazolidinediones) are PPAR $\gamma$ agonists, which improve serum triglycerides and glycaemic control for type 2 diabetes. However, side effects mediated by PPAR $\gamma$ include weight gain in diabetics when such agonists are used for a prolonged time (61, 62 ), an increase in cardiovascular risks and, for rosiglitazone, an increased risk of acute myocardial infarction, stroke, and heart failure (63).

EDCs can probably affect multiple target mammalian cells through a variety of mechanisms. The most likely mechanism involves direct binding to nuclear receptors such as oestrogen receptor $\alpha$ and/or PPAR $\gamma$ acting as agonists. Another possibility would be their binding to nuclear receptors and acting as antagonists. The indirect EDCs' effect involves disrupting hormone levels through the inhibition of enzymatic activity or the activation of expression of P450 enzymes (4).

All proposed mechanisms may also interact with each other creating a complex network. However, in the future, when research studies will have clarified the network of reactions in the cell, a complete picture of interactions will be available. 


\section{Nutrigenomics: nutrient and gene interaction}

Nutrigenomics investigates the effect of interactions between lifestyle, genes (individual genetic variations in single-nucleotide polymorphisms), and food on different/unique responses to food among individuals and consequently, the relationship of that response with the aetiology of common chronic diseases (64, $65)$.

Evolution has brought about minor changes of human genome but these are able to influence an individual's metabolism and response to food (66).

Nutrigenomics is related to the human genome and, as already mentioned, it tries to describe the cause of some chronic diseases (obesity, diabetes mellitus, cancer) through the interactions between genes and the environment (food, pesticides, and pharmaceuticals) (67). It also attempts to create a personalised nutrition for every individual, according to a unique genetic profile $(68,69)$.

The individual advice regarding nutrition and lifestyle changes should be based on an analysis of genes, in order to achieve a better health status (70). When managing multifactorial diseases (including obesity), it is crucial to point out that some genotypes (haplotype combinations) are susceptible to nutrition treatments and that genetic differences among individuals could influence the occurrence of obesity and its health implications (71).

It is important to emphasize that some nuclear transcription factors (e.g. PPAR $\gamma$ ) are more sensitive to nutrition treatment/interventions than others. For example, Kim et al. (72) selected 31 genes in the liver of obese C57BL/6J mice and showed that genes involved in fatty acid beta-oxidation, fatty acid synthesis, and gluconeogenesis were upregulated, but genes involved in sterol biosynthesis, insulin signalling, and oxidative stress defence system were downregulated with a high-fat diet.

Hence, nutrigenomics aims to develop a diet based on individual genetic variants (73) through the research of the influence of such variants on the connections between food and aetiology of obesity (74). It has been shown that individuals with high genetic predisposition for obesity will easily gain weight and will have a different response to weight treatment compared to those with low genetic predisposition (11). Results from studies show that high-fat diets may lead to obesity. One study compared the body mass indexes of individuals according to how much fat they ate and showed that the number of obese individuals was higher among those on a high-fat diet compared with those on a low-fat diet. Also, their body weight changed differently in response to the restriction of calories from fat $(1,75)$.

It is known that interactions between genes, gender, and the environment alternate the development of a disease. In the Framingham Heart Study, interactions between a promoter polymorphism at the apolipoprotein A1 gene, gender, and dietary poly-unsaturated fatty acid intake modulated plasma concentrations of highdensity lipoprotein cholesterol (76), high levels of which protect from cardiovascular diseases.

In another study, Sotos-Prieto et al. (77) showed that the rs 1466113 polymorphism in the somatostatin receptor 2 gene was associated with anthropometric variables in the Mediterranean population with differences in food intake.

Interactions between genes and the environment have also been associated with a decrease in the levels of hormone adiponectin. These changes in adiponectin

Table 2 The list of obesity genes

\begin{tabular}{ll}
\hline $\begin{array}{l}\text { Genotype in obesity } \\
\begin{array}{l}\text { Thriftiness (low metabolic rate, } \\
\text { inadequate thermogenesis) }\end{array}\end{array}$ & $\begin{array}{l}\beta \text {-2-adrenergic receptor and } \beta \text {-3 (ADRB2; ADRB3), uncoupling protein 1, 2, } \\
\text { and 3 (UCP1, UCP2, UCP3) }\end{array}$ \\
\hline $\begin{array}{l}\text { Hyperphagia (abnormal regulation } \\
\text { of hunger and satiety) }\end{array}$ & $\begin{array}{l}\text { dopamine receptor D2 (DRD2); 5-hydroxytryptamine (serotonin) receptor 2C } \\
\text { (HTR2C); leptin (LEP); leptin receptor (LEPR); melanocortin receptor 4 } \\
\text { (MC4R); nuclear receptor subfamily 3, group C, member 1 (NR3C1) }\end{array}$ \\
\hline Low rate of lipid oxidation & $\begin{array}{l}\text { angiotensin-converting enzyme (ACE), adiponectin (ADIPOQ), guanine } \\
\text { nucleotide binding protein, } \beta \text {-3 subunit (GNB3), hormone sensitive lipase } \\
\text { (LIPE), low density lipoprotein receptor (LDLR)] }\end{array}$ \\
\hline Adipogenesis (fat storage) & $\begin{array}{l}\text { peroxisome proliferator-activated receptor } \gamma \text { (PPAR } \gamma \text { ); vitamin D receptor } \\
\text { (VDR), resistin (RETN), interleukin-6 (IL6); tumour necrosis factor } \alpha \text { (TNF)] }\end{array}$ \\
\hline Low physical activity & dopamine receptor D2 (DRD2); melanocortin receptor 4 (MC4R) \\
\hline
\end{tabular}


level can cause obesity. Ntalla et al. (78) investigated whether variants of adiponectin gene interacted with food/specific components of food and influenced the levels of adiponectin. The results of the study, conducted on healthy school-aged children, showed that a single nucleotide polymorphism rs1501299 and fibre interaction was significantly associated with adiponectin levels.

Consumption of refined carbohydrates contributes to the development of obesity and type 2 diabetes mellitus. Most genes of the metabolic pathways of carbohydrates are associated with quantitative trait loci for obesity and many for type 2 diabetes mellitus. It is significant to underline that metabolic pathway genes have a role in the development of a disease and different appearance of such disease among individuals, which results in different risks for a specific disease (79).

Inflammation plays an important role in the development of health implications of obesity (80) and fat tissue is essential, as obesity is associated with inflammation (81): adipocytes, or fat cells, secrete pro- and anti-inflammatory adipokines (82-84). Reduced adiponectin $(85,86)$ and increased Creactive protein $(87,88)$ concentrations are associated with cardiovascular disease and type 2 diabetes. A decrease in inflammation can prevent health complications associated with obesity. Some food has anti-inflammatory effects ( 89 ) and has been associated with the decrease in the prevalence of some chronic diseases related to dietary and lifestyle habits $(90,91)$. In line with this, Bakker et al. (92) conducted a dietary intervention with antioxidative substances such as resveratrol, green tea extract, $\alpha$-tocopherol, vitamin $\mathrm{C}$, omega- 3 polyunsaturated fatty acids, and tomato extract, and showed that these compounds influenced inflammatory processes, oxidative stress, and metabolism in individuals.

How to maintain a healthy weight after low calorie/ low energy treatment is the issue of many studies (93). Peripheral blood mononuclear cells (PBMCs) can help to investigate the response to nutrition interventions (94), and Goyenechea et al. (93) demonstrated the role of pro-inflammatory status in weight changes in obese subjects receiving a low-calorie diet (LCD) during a six-month weight maintenance period. This could help to create individual dietary treatments for maintaining healthy weight. In another study, Goyenechea et al. (95) analysed the expression of two interacting genes (RIPK3 and RNF216) in obese subjects receiving LCD and the authors concluded that the expression of these two genes in PBMCs could identify those obese subjects who will regain more weight after a successful initial weight loss.

\section{Personalised nutrition}

Nutrigenetics and personalised nutrition can give every individual an advice on a diet that is in line with personal genetic profile (96). Arkadianos et al. (70) showed that nutrigenetically (gene-nutrition) tailored diets result in better compliance of patients, longer reduction of body weight, and improvement in glucose blood levels.

Negative public opinion on genetic testing in order to create a unique personalised diet, may influence the success of nutrigenomic intervention. Steward-Knox et al. (97) conducted a study in order to determine the opinion of people in Europe on genetic testing and individually tailored nutrition. Individuals who were willing to undertake a genetic test for creating personalised dietary interventions in most cases had high blood cholesterol levels, central obesity, and/or high levels of stress, whereas individuals who were not obese were not willing to have a nutrigenomic intervention.

To summarise, obesity involves an interaction between genetic and environmental factors (98). This is the reason why it is important to include geneenvironment information in the management and prevention of excess weight. However, some issues of weight management are still crucial (15): identification of markers that can predict the results of dietary interventions; development of methods for identifying biomarkers; simple and available measurement of markers; and responsible use of individual genetic information.

\section{CONCLUSION}

Obesity is caused by the combined impact of genetic, environmental, and lifestyle factors. It represents a risk factor for cardiovascular and metabolic diseases (hypertension, type 2 diabetes, insulin resistance, hyper-insulinaemia, gout, liver disease, gall bladder disease), kidney disease, reproductive problems, sleep apnoea, osteoarthritis, and multiple types of cancer. Overall, it is the culprit for many current health problems in the population of western countries. As the prevalence of obesity continues to increase, it is important to better understand the genetic aspect of obesity and the 
importance of the interactions between genes, genome, epigenome, and the environment obesogens. The disputable and known pharmaceutical and environmental obesogens, such as thiazolidinediones, organotins, perfluorooctanoic acid, diisobutyl phthalate, and bisphenol A, are still used today and should be banned and removed from the environment.

Also, although nutritional interventions can reduce body mass, the process of gaining weight can be affected by an individual genetic profile. Nutrigenomic approach allows us to explore these interactions and apply them in the management of obesity. Many genes in which polymorphisms can affect the development of obesity are identified, but further investigations are still necessary; especially in the development of new diagnostic methods, categorisation of obesity based on specific genotype, creation of personalised nutrition for treating excess weight, and the most important, effective prevention tools. To conclude, the future of nutrigenomics science brings many challenges for scientists, practitioners, caregivers, and individuals. Investigating obesity and its significant health implications is and will continue to be important, as more effective ways need to be found to resolve this public health problem.

\section{Acknowledgement}

This study was supported by a grant No. 05834443466 from the Ministry of Science, Education, and Sports, the Republic of Croatia.

\section{REFERENCES}

1. Papoutsakis C, Dedoussis GV. Gene-diet interactions in childhood obesity: paucity of evidence as the epidemic of childhood obesity continues to rise. Personalized Med 2007;4:133-46.

2. Lau FC, Bagchi M, Sen C, Roy S, Bagchi D. Nutrigenomic analysis of diet-gene interactions on functional supplements for weight management. Curr Genomics 2008;9:239-51.

3. Kopelman P. Health risks associated with overweight and obesity. Obes Rev 2007;8(Suppl 1):13-7.

4. Newbold RR. Impact of environmental endocrine disrupting chemicals on the development of obesity. Hormones 2010;9:206-17.

5. Chlebowski RT. Obesity and early-stage breast cancer. J Clin Oncol 2005;23:1345-7.

6. Sauter ER, Scott S, Hewett J, Kliethermes B, Ruhlen RL, Basarakodu K, de la Torre R. Biomarkers associated with breast cancer are associated with obesity. Cancer Detect Prev 2008;32:149-55.
7. Rose DP, Vona-Davis L. Interaction between menopausal status and obesity in affecting breast cancer risk. Maturitas 2010;66:33-8

8. Strom SS, Wang X, Pettaway CA, Logothetis CJ, Yamamura Y, Do KA, Babaian RJ, Troncoso P. Obesity, weight gain, and risk of biochemical failure among prostate cancer patients following prostatectomy. Clin Cancer Res 2005;11:6889-94

9. Cao Y, Ma J. Body mass index, prostate cancer-specific mortality, and biochemical recurrence: a systematic review and meta-analysis. Cancer Prev Res 2011;4:486-501.

10. Kanasaki K, Koya D. Biology of obesity: lessons from animal models of obesity. J Biomed Biotechnol 2011;2011:197636. doi: 10.1155/2011/197636

11. Agurs-Collins T, Bouchard C. Gene-nutrition and genephysical activity interactions in the etiology of obesity. Obesity 2008;16(Suppl 3):S2-4.

12. Rojas J, Arraiz N, Aguirre M, Velasco M, Bermúdez V. AMPK as target for intervention in childhood and adolescent obesity. J Obes 2011;2011:252817. doi: $10.1155 / 2011 / 252817$

13. Rankinen T, Zuberi A, Chagnon YC, Weisnagel SJ, Argyropoulos G, Walts B, Pérusse L, Bouchard C. The human obesity gene map: the 2005 update. Obesity 2006;14:529644.

14. Bouchard C. The biological predisposition to obesity: beyond the thrifty genotype scenario. Int J Obes 2007;31:1337-9.

15. Bray MS. Implications of gene-behavior interactions: prevention and intervention for obesity. Obesity 2008;16(Suppl 3):S72-8.

16. Vimaleswaran KS, Loo RJF. Progress in the genetics of common obesity and type 2 diabetes. Expert Rev Mol Med 2010;12:e7.

17. Chung WK, Leibel RL. Considerations regarding the genetics of obesity. Obesity 2008;16(Suppl 3):S33-9.

18. Martinez JA, Parra MD, Santos JL, Moreno-Aliaga MJ, Marti A, Martinez-Gonzalez MA. Genotype-dependent response to energy-restricted diets in obese subjects: towards personalized nutrition. Asia Pac J Clin Nutr 2008;117(Suppl 1):119-22.

19. Poehlman EE, Tremblay A, Despres JP, Fontaine E, Pérusse L, Thériault G, Bouchard C. Genotype-controlled changes in body composition and fat morphology following overfeeding in twins. Am J Clin Nutr 1986;43:723-31.

20. Bouchard C, Tremblay A, Despres JP, Nadeau A, Lupien JP, Thériault G, Dussault J, Moorjani S, Pinault S, Fournier G. The response to long-term overfeeding in identical twins. N Engl J Med 1990;322:1477-82.

21. Hainer V, Stunkard AJ, Kunesová M, Parízková J, Stich V, Allison DB. Intrapair resemblance in very low calorie dietinduced weight loss in female obese identical twins. Int $\mathrm{J}$ Obes Relat Metab Disord 2000;24:1051-7.

22. Poehlman EE, Tremblay A, Nadeau A, Dussault J, Thériault $\mathrm{G}$, Bouchard C. Heredity and changes in hormones and metabolic rates with short-term training. Am J Physiol Endocrinol Metab1986;250:E711-7.

23. Bouchard C, Tremblay A, Després JP, Thériault G, Nadeau A, Lupien PJ, Moorjani S, Prudhomme D, Fournier G. The response to exercise with constant energy intake in identical twins. Obes Res 1994;2:400-10.

24. Mammès O, Betoulle D, Aubert R, Giraud V, Tuzet S, Petiet A, Colas-Linhart N, Fumeron F. Novel polymorphisms in 
the $5^{\prime}$ region of the LEP gene: association with leptin levels and response to lowcalorie diet in human obesity. Diabetes 1998;47:487-9.

25. Mammès O, Betoulle D, Aubert R, Herbeth B, Siest G, Fumeron F. Association of the G-2548A polymorphism in the $5^{\prime}$ region of the LEP gene with overweight. Ann Hum Genet 2000,64:391-4.

26. Mammès O, Aubert R, Betoulle D, Péan F, Herbeth B, Visvikis S, Siest G, Fumeron F. LEPR gene polymorphisms: associations with overweight, fat mass and response to diet in women. Eur J Clin Invest 2001;31:398-404.

27. de Luis Roman D, de la Fuente RA, Sagrado MG, Izaola O, Vicente RC. Leptin receptor Lys656Asn polymorphism is associated with decreased leptin response and weight loss secondary to a lifestyle modification in obese patients. Arch Med Res 2006;37:854-9.

28. Lindi V, Sivenius K, Niskanen L, Laakso M, Uusitupa MI Effect of the Pro12Ala polymorphism of the PPAR-gamma2 gene on long-term weight change in Finnish non-diabetic subjects. Diabetologia 2001;44:925-6.

29. Nicklas BJ, van Rossum EF, Berman DM, Ryan AS, Dennis KE, Shuldiner AR. Genetic variation in the peroxisome proliferator-activated receptor-gamma2 gene (Pro12Ala) affects metabolic responses to weight loss and subsequent weight regain. Diabetes 2001;50:2172-6.

30. Choquet H, Meyre D. Genomic insights into early-onset obesity. Genome Med 2010;2:36 [displayed 23 June 2010]. Available at http://genomemedicine.com/content/2/6/36

31. Choquet H, Meyre D. Molecular Basis of Obesity: Current Status and Future Prospects. Curr Genomics 2011;12:15468.

32. Choquet H, Meyre D. Genetics of Obesity: What have we Learned? Curr Genomics 2011;12:169-79.

33. Su LJ, Mahabir S, Ellison GL, McGuinn LA, Reid BC. Epigenetic contributions to the relationship between cancer and dietary intake of nutrients, bioactive food components, and environmental toxicants. Front Genet 2012;2:91 [displayed 9 January 2012]. Available at http://www.ncbi. nlm.nih.gov/pmc/articles/PMC3266615/pdf/fgene-02-00091. pdf

34. Lau C, Abbott BD, Corton JC, Cunningham ML. PPARs and Xenobiotic-Induced Adverse Effects: Relevance to Human Health. PPAR Res 2010;2010:954639. [displayed 7 June 2011]. Available at http://www.ncbi.nlm.nih.gov/pmc/ articles/PMC3124005/?tool=pubmed

35. Diamanti-Kandarakis E, Bourguignon J-P, Giudice LC, Hauser R, Prins GS, Soto AM, Zoeller RT, Gore AC. Endocrine-disrupting chemicals: An endocrine society scientific statement. Endocrine Rev 2009;30:293-342.

36. Jin-Qiang C, Brown TR, Russo J. Regulation of energy metabolism pathways by estrogens and estrogenic chemicals and potential implications in obesity associated with increased exposure to endocrine disruptors. Biochim Biophys Acta 2009;1793:1128-43.

37. Stienstra R, Duval C, Müller M, Kersten S. PPARs, obesity, and inflammation. PPAR Res 2007;2007:95974. [displayed 28 December 2006]. Available at http://www.ncbi.nlm.nih. gov/pmc/articles/PMC1783744/

38. Greiner T, Bäckhed F. Effects of the gut microbiota on obesity and glucose homeostasis. Trends Endocrinol Metab 2011;22:117-23.
39. Giovanni M, Gambino R, Cassader M. Obesity, diabetes, and gut microbiota: the hygiene hypothesis expanded? Diabetes Care 2010;33:2277-84.

40. Everard A, Lazarevic V, Derrien M, Girard M, Muccioli GG, Neyrinck AM, Possemiers S, Van Holle A, François P, de Vos WM, Delzenne NM, Schrenzel J, Cani PD. Responses of gut microbiota and glucose and lipid metabolism to prebiotics in genetic obese and diet-induced leptin-resistant mice. Diabetes 2011;60:2775-86.

41. Geurts L, Lazarevic V, Derrien M, Everard A, Van Roye M, Knauf C, Valet P, Girard M, Muccioli GG, François F, de Vos WM, Schrenzel J, Delzenne NM, Cani PD. Altered gut microbiota and endocannabinoid system tone in obese and diabetic leptin-resistant mice: impact on apelin regulation in adipose tissue. Front Microbiol 2011;2:149. [displayed 13 July 2011]. Available at http://www.ncbi.nlm.nih.gov/pmc/ articles/PMC3139240/?tool=pubmed

42. McAllisterEJ, DhurandharNV, Keith SW, Aronne LJ, Barger J, Baskin M, Benca RM, Biggio J, Boggiano MM, Eisenmann JC, Elobeid M, Fontaine KR, Gluckman P, Hanlon EC, Katzmarzyk P, Pietrobelli A, Redden DT, Ruden DM, Wang C, Waterland RA, Wright SM, Allison DB. Ten putative contributors to the obesity epidemic. Crit Rev Food Sci Nutr 2009;49:868-913.

43. Steger DJ, Lazar MA. Adipogenic hotspots: where the action is. EMBO J 2011;30:1418-9.

44. Ahima RS. Digging deeper into obesity J Clin Invest 2011;121:2076-9.

45. Grün F, Blumberg B. Environmental obesogens organotins and endocrine disruption via nuclear receptor signaling. Endocrinology 2006;147(Suppl 6):S50-5.

46. Casals-Casas C, Feige JN, Desvergne B. Interference of pollutants with PPARs: endocrine disruption meets metabolism. Int J Obes 2008;32(Suppl 6):S53-61.

47. Grün F, Blumberg B. Minireview: the case for obesogens. Mol Endocrinol 2009;23:1127-34.

48. Grün F, Blumberg B. Endocrine disrupters as obesogens. Mol Cell Endocrinol 2009;304:19-29.

49. Kirchne S, Kieu T, Chow C, Casey S, Blumberg B. Prenatal exposure to the environmental obesogen tributyltin predisposes multipotent stem cells to become adipocytes. Mol Endocrinol 2010;24:526-39.

50. Tsuda T, Inoue T, Kojima M, Aoki S. Daily intakes of tributyltin and triphenyltin compounds from meals. J AOAC Int 1995;78:941-3.

51. Guérin T, Sirot V, Volatier JL, Leblanc JC. Organotin levels in seafood and its implications for health risk in high-seafood consumers. Sci Total Environ 2007;388:66-77.

52. Ohno H, Suzuki M, Nakashima S, Aoyama T, Mitani K. [Determination of organotin compounds in plastic products by GC/MS after ethyl derivatization with sodium tetraethylborate, in Japanese]. Shokuhin Eiseigaku Zasshi 2002;43:208-14.

53. Grün F, Watanabe $\mathrm{H}$, Zamanian Z, Maeda L, Arima K, Cubacha R, Gardiner DM, Kanno J, Iguchi T, Blumberg B. Endocrinedisrupting organotin compounds are potent inducers of adipogenesis in vertebrates. Mol Endocrinol 2006;20:2141-55.

54. Decherf S, Demeneix BA. The obesogen hypothesis: a shift of focus from the periphery to the hypothalamus. J Toxicol Environ Health B Crit Rev 2011;14:423-48. 
55. Wetherill YB, Akingbemi BT, Kanno J, McLachlan JA, Nadal A, Sonnenschein C, Watson CS, Zoeller RT, Belcher SM. In vitro molecular mechanisms of bisphenol A action. Reprod Toxicol 2007;24:178-98.

56. Richter CA, Birnbaum LS, Farabollini F, Newbold RR, Rubin BS, Talsness CE, Vandenbergh JG, Walser-Kuntz DR, vom Saal FS. In vivo effects of bisphenol A in laboratory rodent studies. Reprod Toxicol 2007;24:199-224

57. Somm E, Schwitzgebel VM, Toulotte A, Cederroth CR, Combescure C, Nef S, Aubert ML, Hüppi PS. Perinatal exposure to bisphenol a alters early adipogenesis in the rat Environ Health Perspect 2009;117:1549-55.

58. Rubin BS, Murray MK, Damassa DA, King JC, Soto AM. Perinatal exposure to low doses of bisphenol A affects body weight, patterns of estrous cyclicity, and plasma LH levels. Environ Health Perspect 2001;109:675-80.

59. Nikaido Y, Danbara N, Tsujita-Kyutoku M, Yuri T, Uehara $\mathrm{N}$, Tsubura A. Effects of prepubertal exposure to xenoestrogen on development of estrogen target organs in female CD-1 mice. In Vivo 2005;19:487-94.

60. Honma S, Suzuki A, Buchanan DL, Katsu Y, Watanabe H, Iguchi T. Low dose effect of in utero exposure to bisphenol A and diethylstilbestrol on female mouse reproduction. Reprod Toxicol 2002;16:117-22.

61. Goldberg RB. The new clinical trials with thiazolidinediones - DREAM, ADOPT, and CHICAGO: promises fulfilled? Curr Opin Lipidol 2007;18:435-42.

62. Tiwari HK, Patki A, Lieberman J, Stroup TS, Allison DB, Leibel RL, Chung WK. Association of allelic variation in genes mediating aspects of energy homeostasis with weight gain during administration of antipsychotic drugs (CATIE Study). Front Genet 2011;2:56 [displayed 1 September 2011]. Available at http://www.ncbi.nlm.nih.gov/pmc/ articles/PMC3202977/?tool=pubmed

63. Graham JD, Ouellet-Hellstrom R, MaCurdy TE, Farzana Ali F, Christopher Sholley C, Worrall C, Kelman JA. Risk of acute myocardial infarction, stroke, heart failure, and death in elderly Medicare patients treated with rosiglitazone or pioglitazone. JAMA 2010;304:411-8.

64. Agurs-Collins T, Khoury MJ, Simon-Morton D, Olster DH Public health genomics: translating obesity genomics research into population health benefits. Obesity 2008;16(Suppl 3):S85-94.

65. Caulfield T, Shelley J, Alfonso V, Bubela T. Nutrigenomics and the promise of prevention: representations and realities. Health Law J 2008;1:41-66.

66. Lairon D, Defoort C, Martin JC, Amiot-Carlin MJ, Gastaldi M, Planells R. Nutrigenetics: links between genetic background and response to Mediterranean-type diets. Public Health Nutr 2009;12:1601-6.

67. Miggiano GA, De Sanctis R. [Nutritional genomics: toward a personalized diet, in Italian]. Clin Ter 2006;157:355-61.

68. Nutritional outlook. The future of Nutrigenomics [displayed 16 October 2006]. Available at http://www.nutritionaloutlook. com/article/future-nutrigenomics

69. Bašić M, Zrnec D, Butorac A, Landeka Jurčević I, Đikić D, Bačun-Družina V. Što je nutrigenomika? [What is nutrigenomics? in Croatian]. Croat J Food Technol Biotechnol Nutr 2011;6:37-44

70. Arkadianos I, Valdes AM, Marinos E, Florou A, Gill RD, Grimaldi KA. Improved weight management using genetic information to personalize a calorie controlled diet. Nutr J
2007;6:29 [displayed 18 October 2007]. Available at http:// www.ncbi.nlm.nih.gov/pmc/articles/PMC2151062/

71. Gorduza EV, Indrei LL, Gorduza VM. Nutrigenomics in postgenomic era. Rev Med Chir Soc Med Nat Iasi 2008;112:152-64.

72. Kim EJ, Kim E, Kwon EY, Jang HS, Hur CG, Choi MS. Network analysis of hepatic genes responded to high-fat diet in $\mathrm{C} 57 \mathrm{BL} / 6 \mathrm{~J}$ mice: nutrigenomics data mining from recent research findings. J Med Food 2010;13:743-56.

73. Lévesque L, Ozdemir V, Godard B. Socio-ethical analysis of equity in access to nutrigenomics interventions for obesity prevention: a focus group study. OMICS 2008;12:273-8.

74. Steemburgo T, Azevedo MJ, Martínez JA. [Gene-nutrient interaction and its association with obesity and diabetes mellitus, in Portuguese]. Arq Bras Endocrinol Metabol 2009;53:497-508

75. Tapsell LC, Probst YC. Nutrition in the prevention of chronic diseases. World Rev Nutr Diet 2008;98:94-105.

76. Ordovas JM. Genotype-phenotype associations: modulation by diet and obesity. Obesity 2008;16(Suppl 3):S40-6.

77. Sotos-Prieto M, Guillén M, Guillem-Sáiz P, Portolés O, Corella D. The rs 1466113 polymorphism in the somatostatin receptor 2 gene is associated with obesity and food intake in a Mediterranean population. Ann Nutr Metab 2010;57:12431.

78. Ntalla I, Dedoussis G, Yannakoulia M, Smart MC, Louizou E, Sakka SD, Papoutsakis C, Talmud PJ. ADIPOQ gene polymorphism rs 1501299 interacts with fibre intake to affect adiponectin concentration in children: the GENe-Diet Attica Investigation on childhood obesity. Eur J Nutr 2009;48:4937.

79. Varma V, Wise C, Kaput J. Carbohydrate metabolic pathway genes associated with quantitative trait loci (QTL) for obesity and type 2 diabetes: identification by data mining. Biotechnol J 2010;5:942-9.

80. Stryjecki C, Mutch DM. Fatty acid-gene interactions, adipokines and obesity. Eur J Clin Nutr 2011;65:285-97.

81. Hotamisligil GS. Inflammation and metabolic disorders. Nature 2006;444:860-7.

82. Ronti T, Lupattelli G, Mannarino E. The endocrine function of adipose tissue: an update. Clin Endocrinol 2006;64:355-65.

83. Trayhurn P, Beattie JH. Physiological role of adipose tissue: white adipose tissue as an endocrine and secretory organ. Proc Nutr Soc 2001;60:329-39.

84. Wang P, Mariman E, Renes J, Keijer J. The secretory function of adipocytes in the physiology of white adipose tissue. J Cell Physiol 2008;216:3-13.

85. Pischon T, Girman CJ, Hotamisligil GS, Rifai N, Hu FB, Rimm EB. Plasma adiponectin levels and risk of myocardial infarction in men. JAMA 2004;291:1730-7.

86. Schulze MB, Rimm EB, Shai I, Rifai N, Hu FB. Relationship between adiponectin and glycemic control, blood lipids, and inflammatory markers in men with type 2 diabetes. Diabetes Care 2004;27:1680-7.

87. Hu FB, Meigs JB, Li TY, Rifai N, Manson JE. Inflammatory markers and risk of developing type 2 diabetes in women. Diabetes 2004;53:693-700.

88. Danesh J, Wheeler JG, Hirschfield GM, Eda S, Eiriksdottir G, Rumley A, Lowe GD, Pepys MB, Gudnason V. C-reactive protein and other circulating markers of inflammation in 
the prediction of coronary heart disease. N Engl J Med 2004;350:1387-97.

89. Puglisi MJ, Fernandez ML. Modulation of C-reactive protein, tumor necrosis factor- $\alpha$, and adiponectin by diet, exercise, and weight loss. J Nutr 2008;138:2293-6.

90. Trichopoulou A, Bamia C, Trichopoulos D. Anatomy of health effects of Mediterranean diet: Greek EPIC prospective cohort study. B M J 2009;338:b2337. [displayed 23 June 2009]. Available at http://www.ncbi.nlm. nih.gov/pmc/articles/PMC3272659/?tool=pubmed

91. Esposito K, Marfella R, Ciotola M, Di Palo C, Giugliano F, Giugliano G, D'Armiento M, D'Andrea F, Giugliano D. Effect of a Mediterranean-style diet on endothelial dysfunction and markers of vascular inflammation in the metabolic syndrome: a randomized trial. JAMA 2004;292:1440-6.

92. Bakker GC, van Erk MJ, Pellis L, Wopereis S, Rubingh CM, Cnubben NHP. An antiinflammatory dietary mix modulates inflammation and oxidative and metabolic stress in overweight men: a nutrigenomics approach. Am J Clin Nutr 2010;91:1044-59.

93. Goyenechea E, Parra D, Crujeiras AB, Abete I, Martínez JA. A nutrigenomic inflammation-related PBMC-based approach to predict the weight-loss regain in obese subjects. Ann Nutr Metab 2009;54:43-51.

94. Caimari A, Oliver P, Keijer J, Palou A. Peripheral blood mononuclear cells as a model to study the response of energy homeostasis-related genes to acute changes in feeding conditions. OMICS 2010;14:129-41.

95. Goyenechea E, Crujeiras AB, Abete I, Martínez JA. Expression of two inflammation-related genes (RIPK3 and RNF216) in mononuclear cells is associated with weight-loss regain in obese subjects. J Nutrigenet Nutrigenomics 2009;2:78-84.

96. Rimbach G, Minihane AM. Nutrigenetics and personalised nutrition: how far have we progressed and are we likely to get there. Proc Nutr Soc 2009;68:162-72.

97. Stewart-Knox BJ, Bunting BP, Gilpin S, Parr HJ, Pinhão S, Strain JJ, de Almeida MD, Gibney M. Attitudes toward genetic testing and personalised nutrition in a representative sample of European consumers. Br J Nutr 2009;101:982-9.

98. Alfredo Martínez J, Martínez-Hernández A, Enríquez L, Moreno-Aliaga MJ, Moreno-Moreno MJ, Martí A. Genetics of obesity. Public Health Nutr 2007;10:1138-44. 


\section{Sažetak}

\section{PRETILOST - MEĐUDJELOVANJE GENOMA I OKOLINE}

U industrijaliziranom svijetu među odraslim osobama, adolescentima i djecom pretilost je postala jedna od glavnih prijetnja za javno zdravlje ljudi. Njezina je pojavnost pod utjecajem međudjelovanja gena, prehrane, okoliša i načina života. Važni čimbenici rizika vezani su uz okolinu i način života, uključujući čimbenike prisutne već u okruženju fetusa te one prisutne tijekom cijeloga života kao što su kvaliteta prehrane, izloženost kemikalijama, mikroorganizmima i psihičkom stresu. Uklanjanje ili ograničavanje kemijskih tvari i lijekova koji uzrokuju pretilost iz ljudske okoline moglo bi utjecati na opadanje epidemije pretilosti.

Dodatno, nutrigenomika opisuje kako se promjenama u prehrani pojedinca može poboljšati zdravstveno stanje i spriječiti razvoj kroničnih bolesti, uključujući i pretilost, a pritom je potrebno poznavati utjecaj genskog profila na međudjelovanje hrane i porasta tjelesne mase. Nadalje, genske varijacije u genomu pojedinih osoba stvaraju i njihovu predispoziciju za razvoj pretilosti. Stoga se zahvaljujući informacijama o genskom profilu pojedinca, izbjegavanjem tvari koje uzrokuju pretilost i zdravim načinom života može poboljšati kontrola pretilosti i održavati optimalna tjelesna masa.

KLJUČNE RIJEČI: geni, nutrigenomika, prehrana, tvari koje uzrokuju pretilost

\section{CORRESPONDING AUTHOR:}

Višnja Bačun-Družina

Faculty of Food Technology and Biotechnology

University of Zagreb

P.O. Box 625, HR-10001 Zagreb, Croatia

E-mail:visnjabd@pbf.hr 